\title{
Evolving strategies of the predatory journals
}

\author{
Alexandru-lonuţ Petrişor ${ }^{1,2}$ \\ ${ }^{1}$ Department of Urban and Landscape Planning "Ion Mincu" \\ University of Architecture and Urban Planning, Str. Academic nr. 18-20, sector 1, \\ cod 010014, Bucharest, ROMANIA \\ ${ }^{2}$ URBAN-INCERC National Institute for Research and Development in Constructions, Urban \\ Planning and Sustainable Spatial Development, Sos. Pantelimon, nr. 266, sector 2, \\ cod 021652, Bucharest, ROMANIA \\ e-mail: alexandru.petrisor@uauim.ro; alexandru_petrisor@yahoo.com
}

\begin{abstract}
.
Along with the increasing use of the Internet, scholarly publishing was affected by the rise of 'predatory journals'. Many authors attribute the success of these journals to the open access provided to potential readers. While many authors have attempted to propose criteria for identifying predatory journals, very little research was directed to explaining their success, and underlying strategies. This study uses a biological sciences perspective, based on the five stages of predation, and examines the strategies accordingly. The results indicate that predatory journals use the same strategies as all Internet-based scams in identifying their prey. The largest number of strategies addresses approaching the authors. The recent trends include personalized call for papers, use of fake metrics, hijacking reputed journals, faking location and editorial structure, addressing a broad range of topics and providing fast services (at the expense of quality). In addition to these strategies, publishing fees are often hidden. In summary, the pressure to publish and metrics-based career advancement procedures are the main attractors driving authors to predatory journals, despite the efforts of scientists and Internet-based means of identifying these journals and publicizing their dishonest practices.
\end{abstract}

Keywords: Open Access journals; Predatory journals; Journal studies; Journal Impact Factor, Trustworthiness.

\section{INTRODUCTION}

The term 'predatory journals' has been coined by the American academic librarian and researcher Jeffrey Beall in 2008 (Butler 2013). Although the term originates from biological sciences, referring to consuming or devouring the others, it has been extensively used in economics, especially in relationship to the strategy of a company against its competitors (Easterbrook 1981), and expanded its meaning over getting someone else's money. Jeffrey Beall uses the term in the sense of "inclined or intended to injure or exploit others for personal gain or profit" (Crawford 2014, p. 3). Beall is also the creator of a list of potential predatory journals (Beall 2015), which has grown extensively to include 18 publishers in 2010 (Beall 2010a; 2010b; 2013), 23 in 2011, over 225 in 2012 (Beall 2013), over 300 in 2013 (Butler 2013) and over 475 in 2014 (Butler-Adam 2014).

From the beginning, the list contained open-access journals, leading to debates focused on discerning between 'legitimate open access journals' and the 'predatory' ones (Beall 
2012a; Truth 2012; Haug 2013; Bartholomew 2014; Wehrmeijer 2014), and particular criticisms addressed to Beall's List (Beall 2015) for its inability to properly distinguish between the two (Crawford 2014; Fiebert 2014). As a result, sets of criteria for identifying potential predatory journals and publishers have been proposed (Beall 2010a, 2015; Eklund 2012; Truth 2012; Butler 2013; Haug 2013; Crawford 2014; Dyrud 2014; Lukić et al. 2014; Schauss 2014; Wehrmeijer 2014). The confusion is particularly important for journals listed with the Sweden-based Directory of Open Access Journals (DOAJ), which has consequently revised its listing policy (Bohannon 2013; Butler 2013; Burns 2014; Anderson 2014; Wehrmeijer 2014) to prevent the inclusion of 'predatory journals'. Another cause of their sprawl seems to be globalization (Crawford 2014).

Probably the most important characteristic of 'predatory journal' is the lack of quality control, situated at the core of the reactions of scientific communities from all over the world against them. Recent examples included bogus papers published or accepted by the scientific community, such as 2009 bogus paper "Deconstructing access points" written by Cornell University's doctoral student, David Phillips, and accepted by The Open Information Science Journal (Dyrud 2014) or M. Rathke's "Independent, negative, canonically Turing arrows of equations and problems in applied formal PDE " (Eldredge 2012), the 'Sting operation' of John Bohannon (2013) ending with the acceptance of his spoof paper by 157 journals and rejection by only 98 (Bohannon 2013; Bartholomew 2014; Burns 2014; ButlerAdam 2014; Crawford 2014; Lukić et al. 2014; Wehrmeijer 2014), or the senseless paper "Evaluation of transformative hermeneutic heuristics for processing random data" published by Metalurgia International (Dyrud 2014; Lukić et al. 2014), and other similar examples. A hilarious example is the article "Mapping Indonesian paddy fields using multiple-temporal satellite imagery", published in July 2012 by the predatory African Journal of Agricultural Research, a slightly changed copy of the article "Mapping Indonesian rice areas using multiple-temporal satellite imagery", also published by a predatory publication - the Scholarly Journal of Agricultural Science, replacing the names of two authors those of two popular Indonesian entertainers, Agnes Monica and Inul Daratista (Beall 2012a). Despite this already publicized situation, checking the websites of journals from Beall's List shows that they continue to publish; researchers are still receiving calls for papers (CFPs) from them; and new predatory journals appear each week. The question is, 'What keeps the system going on?' To answer this question, this paper examines several strategies common to predatory journals.

\section{OBJECTIVE AND METHOD}

The research presented in this article aims to identify the strategies of the predatory journals using the five stages of predation as a theoretical lens. The analogy with biological predation can include the five stages of predation (Endler 1986): detection, identification, approach, subjugation, and consumption; in this case, the 'detection' consists of finding authors who have published in other journals; 'identification' consists of getting their contacts; the 'approach' is stage starting with the CFPs' and ending with the author paying no attention or being subjugated; 'subjugation' is the submission stage; and 'consumption' coincides with charging the author. Most of the strategies are involved in the 'approach', and few in the next stages. The strategies used in the stages preceding the 'approach' are common to the ones of any scam involving contacting a person found via the Internet in order to obtain material advantages. 
Data used in the analysis comprise e-mail based CFPs from the predatory journals and conferences received by the author and his colleagues during the last years, and collateral data sources, including, without limiting to, Beall's list (http://scholarlyoa.com/), the scholarly kitchen (http://scholarlykitchen.sspnet.org/) and other similar websites. The data were grouped according to the five stages of predation. The data sources used to exemplify the points made throughout the presentation were selected from over 500 CFPs during the last years.

- 2014 International Conference on Advanced Education Reform and Management Innovation. CFP received via e-mail 2014. Similar example also available at http://emailscams-capital-one.blogspot.ro/2014/04/profwang-vip.html

- 3rd World Congress on Cell Science \& Stem Cell Research. CFP received via e-mail 2014.

- Ambit Journals. CFP received via e-mail 2015.

- American Association for Science and Technology. Multiple CFPs received via e-mail 2015.

- American International Journal of Social Science. CFP received via e-mail 2015.

- American Research Journal of Chemistry. CFP received via e-mail 2015.

- Asian Journal of Economics and Empirical Research. CFP received via e-mail 2015.

- Association for Development in Engineering Research. CFP received via e-mail 2015.

- Biochemistry \& Molecular Biology Letters. CFP received via e-mail 2015.

- BioMed Research International. CFP received via e-mail 2015.

- British Journal of Applied Science \& Technology. CFP received via e-mail 2015.

- British Journal of Mathematics \& Computer Science. CFP received via e-mail 2015. Similar example also available at http://journals-details.blogspot.ro/2013/05/cfpbritish-journal-of-mathematics.html

- CIBTech Scientific Journals. CFP received via e-mail 2015.

- Donnish Journals. CFP received via e-mail 2015.

- Elective Medicine Journal. CFP received via e-mail 2015.

- Enliven: Bio Analytical Techniques. CFP received via e-mail 2015.

- Geoinformatics \& Geostatistics. CFP received via e-mail 2014.

- Global Advanced Research Journal of Arts and Humanities. CFP received via e-mail 2015. Similar example also available at http://web-archive-pt.com/pt/u/utl.pt/2015-0228_5502607_41/Ciclo_de_Confer\%C3\%AAncias/

- Global Conference on Applied Social Science. CFP received via e-mail 2015.

- Global Journal of Advanced Research. CFP received via e-mail 2015.

- Global Journal of Science Frontier Research. CFP received via e-mail 2014. Similar example also available at http://www.seehuhn.de/blog/131

- Herbert Publications. CFP received via e-mail 2015.

- International Journal of Advanced and Innovative Research. CFP received via e-mail 2015.

- Indian Journal of Applied Research. CFP received via e-mail 2015.

- Indian Journal of Research. CFP received via e-mail 2015.

- Integrated Journal of Engineering Research and Technology. CFP received via e-mail 2014. Similar example also available at http://www.ijert.co/Default.aspx?pageid=20

- International Journal of Advanced Computer Technology. Multiple CFPs received via email 2015.

- International Journal of Advanced Research in Chemical Science. CFP received via e-mail 2015.

- International Journal of Applied Science and Technology. Multiple CFPs received via email 2015.

- International Journal of Computers and Technology. CFP received via e-mail 2014. 
- International Journal of Emerging Technology and Advanced Engineering. CFP received via e-mail 2015. Similar example also available at http://www.ijetae.com/

- International Journal of Engineering Science and Innovative Technology. CFP received via e-mail 2014. Similar example also available at https://mail.gna.org/public/servicetech-tools/2014-04/msg00002.html

- International Journal of Geosciences. CFP received via e-mail 2015.

- International Research Journal of Engineering and Technology. CFP received via e-mail 2015.

- International Research Journal of Public and Environmental Health. CFP received via email 2015.

- Jacobs Publishers. Multiple CFPs received via e-mail 2015.

- Journal of Architectural Engineering Technology. CFP received via e-mail 2015.

- Journal of Astrobiology \& Outreach. CFP received via e-mail 2015.

- Journal of Biodiversity Management \& Forestry. Multiple CFPs received via e-mail 2015.

- Journal of Biosensors \& Bioelectronics. CFP received via e-mail 2015.

- Journal of Civil Engineering and Architecture. CFP received via e-mail 2014. Similar example also available at https://groups.google.com/forum/\#!topic/ aeesorg/LhvVcQoau-4

- Journal of Current Computer Science and Technology. CFP received via e-mail 2015.

- Journal of Education and Human Development. Multiple CFPs received via e-mail 2015.

- Journal of Emerging Trends in Computing and Information Sciences. CFP received via email 2015.

- Journal of Environmental Analytical Chemistry. CFP received via e-mail 2015.

- Journal of Functional Foods in Health and Disease. CFP received via e-mail 2015.

- Journal of General Medicine - Open Access. CFP received via e-mail 2015.

- Journal of Geography and Earth Sciences. CFP received via e-mail 2015.

- Journal of Global Economics, Management and Business Research. CFP received via email 2015.

- Journal of Global Resources. CFP received via e-mail 2015.

- Journal of Scientific Research and Studies. CFP received via e-mail 2015. Similar example also available at https://groups.yahoo.com/neo/groups/cohrep2005/ conversations/messages/1130

- Multidisciplinary Journal Ciência e Técnica. CFP received via e-mail 2015.

- Open Environmental Engineering Journal. CFP received via e-mail 2015. Similar example also available at http://dept.sci.tu.ac.th/cstu/index.php?option=com_content \&view $=$ category\&id $=88 \&$ ltemid $=435 \&$ limitstart $=88$

- Open Science. Multiple CFPs received via e-mail 2015.

- Pacesetter Journal of Agricultural Science Research. CFP received via e-mail 2015. Similar example also available at http://biodataofdrvhp.blogspot.ro/2013/04/call-forpapers_25.html

- Pak Publishing Group. CFP received via e-mail 2015.

- Research Journal of Engineering and Technology. CFP received via e-mail 2015.

- Savant Journals. CFP received via e-mail 2015.

- Scholars World - International Refereed Multidisciplinary Journal of Contemporary Research. CFP received via e-mail 2015.

- Sci-Afric Journal of Scientific Issues, Research and Essays. CFP received via e-mail 2015.

- Science and Education Publishing. CFP received via e-mail 2015.

- ScienceDomain International. Available at http://www.sciencedomains.org/page.php? id=publication-charge.

- SciencePG. Multiple CFPs received via e-mail 2015. Similar example also available at http://arthur.shumwaysmith.com/life/content/lead_guest_editor_of_a_special_issue. 
- Sky Journal of Agricultural Research. CFP received via e-mail 2015.

- Sky Journals of Biochemistry Research. CFP received via e-mail 2015.

- SOJ Microbiology \& Infectious Diseases. CFP received via e-mail 2015.

- Swift Journals. CFP received via e-mail 2015.

- TimeLine Publications. Multiple CFPs received via e-mail 2015.

- WatchPlus. CFP received via e-mail 2015.

\section{FINDINGS}

\section{Approach Strategies}

Since the entire operation of predatory open-access journals takes place online, the most common way to approach authors is to send the CFPs via mass e-mail (Eklund 2012; Schauss 2014; Wehrmeijer 2014). Obviously, in the previous stages potential authors are identified based on their publications in other journals or conference proceedings, and their contacts gathered from these publications. Nevertheless, people with no scholarly publishing experience, but whose contacts were found online, received such calls. Most authors agree that the poor command of English language is a common characteristic of these calls (Eklund 2012; Truth 2012; Bohannon 2013; Crawford 2014).

There are several elements of the CFP that might constitute common distinctive features of the predatory journals:

a) Journal name (source of names: Beall's list): Although there seems to be an evolution, the limited number of titles in the early lists might explain why some types of titles were not present in the first lists. A possible timeline includes:

- 2009 and earlier: some of the first titles were clearly tied from a geographical standpoint to Africa and Asia, e.g. the African Journal of Business Management, African Journal of Biotechnology, or African Journal of Agricultural Research; 'neutral' titles, such as Bentham Publishing or Academic Journals, start to appear;

- 2010: the list includes 'brand' publishers: Medwell Journals or David Publishing;

- 2011: the list includes generic titles (Academic Journals or Scientific Journals); titles containing the words 'International' (International Research Journals) or 'Global' (Global Open Journals) appear;

- 2012-2013: the names contain geographic locations, real (African Research Review, Indian Journal of Applied-Basic Medical Sciences), fake (US, UK, Australia or Canada): Australian Journal of Basic and Applied Sciences, American Scientific Research Journals, American V-King Scientific Publishing, or Canadian Journal of Applied Sciences or extended (Interlink Continental Journal of Social Science and Humanities, or Atlantic Journals), generic names (Academy Publish, Greener Journals, Elixir Online Journal, Pelagia Research Library Journals, Pyrex Journals, Apex Journal International, or Prime Journals), titles containing the words 'International', 'Global' etc. (Global Journal of Management Science and Technology, International Journal of Engineering Research and Applications), words related to the academic world (Scholoxy International Publications, Academia Journal of Scientific Research, or Scholarena Journals) or motivational words (in bold) (NobleResearch Publishers, International Invention Journal of Education and General Studies, Merit Research Journals, Savant Journals, Peak Journal of Social Sciences and Humanities, Nextgen Research Publication, Sky Journal of Agricultural Research, or Ambit Journals), journals with a very broad scope (Journal of Comprehensive Research), and even 'credible' names, which are not common to 
predatory journals (Journal of Applied Pharmacy, Pharmacologia); in addition, the first hijacked journals appear.

Several words are common to many titles or CFPs: 'advanced', 'scientific', 'scholarly peer-reviewed', 'leading publisher' (Schauss 2014; Wehrmeijer 2014). Furthermore, Crawford (2014) found out that there are 74 'Indian Journal of...', 247 titles starting with 'Global', 300 with 'Open' (176 'Open Journal...' and 228 'The Open...'), 114 'Research Journal of...', 131 'Research Open Journal of...', and 2,208 'International Journal...'. Titles often repeat or overlap: Scientific Research and Essays, Standard Scientific Research and Essays, or International Journal of Scientific Research and Essays. Emerging common words are 'Modern', 'Innovative', 'Green', 'Progressive', 'Ingenious', and 'Standard'. Relatively recently, famous journals were hijacked by creating fake predatory websites or online sites for journals which exist only in print form: Wulfenia, Archives des Sciences, Jökull, Bothalia, Pensée, Sylwan, Ciencia e tecnica vitivinicola, or CADMO (Bell 2012; Butler 2013; Lukić et al. 2014); in addition, the predatory journals broadened the initial scope: Wulfenia, specialized in plant biology, became 'Multidisciplinary Wulfenia', covering all possible subjects.

b) Journal location. Several authors have noticed that most current names include words like 'global', 'international', 'universal', or 'world' (Butler 2013; Dyrud 2014). This strategy can be seen as an attempt to mask the real location, in addition to faking it in the title or address, included in the invitation of found on the website: the address is in the US, UK, Australia or Canada (Beall 2010b, 2012; Crawford 2014; Dyrud 2014; Schauss 2014; Wehrmeijer 2014). Most of them seem to be located in India, "where new predatory publishers or journals emerge each week" (Beall 2012a p. 789), Pakistan or Nigeria (Beall 2012a; Wehrmeijer 2014). Also, the address is not always mentioned in the CFPs or on the websites (Wehrmeijer 2014). An emerging strategy is to rent office addresses in the US or the UK, and include American or British in the journal name, although the business is run from another country (India etc.). A ridiculous situation is the resulting oxymoronic name American International Journal of... (Biology, Contemporary Scientific Research, Research in Formal, Applied and Natural Sciences etc.)

c) Journal subject. In most cases, predatory journals have a broad coverage of subjects and topics (Eklund 2012; Haug 2013; Burns 2014; Dyrud 2014; Schauss 2014; Wehrmeijer 2014), combining fields that are more or less related (Schauss 2014), or even lacking a specific field (Journal of Comprehensive Research, Scientific Research and Essays, Standard Scientific Research and Essays, or International Journal of Scientific Research and Essays). For example, the Journal of Scientific Research and Studies covers, according to the CFP, "Biomedical and Life Sciences, Chemistry and Materials Science, Computer Science and Communications, Earth and Environmental Sciences, Engineering, Medicine and Healthcare, Physics and Mathematics and finally Social Sciences and Humanities" through "Research Papers, Working Papers, Short Communications, Case Studies and Literature Surveys". Also, the Global Advanced Research Journal of Arts and Humanities "is dedicated to increasing the depth of the subject across disciplines with the ultimate aim of expanding knowledge of the subject", although the subject is not stated, similar to the American Research Journal of Chemistry, which "is an online open access journal publishing monthly for Scientists, Professors, and Research Scholars to publish high quality papers with great impact" (please note the English level, contrasting with an 'American' journal). Last but not least, the Indian Journal of Applied Research claims to be a "Journal for All Subjects" (statement listed on al pages of the CFP). 
d) Fast publication. Most predatory journal promise a shorter review cycle (Eklund 2012; Truth 2012; Crawford 2014; Dyrud 2014; Schauss 2014), or provide the author an option to shorten it by paying a certain amount (Crawford 2014). To illustrate this statement, the International Journal of Emerging Technology and Advanced Engineering mentions in its CFP for Volume 5, Issue 2 of February 2015 that the submission deadline is February 05, 2015, and the publication date, February 20, 2015. The 'record' shortest times are mentioned by Ambit Journals (48 hours) and Indian Journal of Research (3 days).

e) Abstracting and indexing. This is often used as a principal attractor; some of the oldest predatory journals (African Journal of Business Management, African Journal of Biotechnology, and African Journal of Agricultural Research) were indexed in ThomsonReuters - Institute of Scientific Information (ISI) database, although they were unlisted later (Eklund 2012; Truth 2012; Dyrud 2014); starting with 2013, fake indexes were created (Jalalian and Mahboobi 2013; Burns 2014); although they are often listed as 'ISI', in fact they are GISI - Global Institute for Scientific Information; the Impact Factor (IF) is replaced by Google-based Impact Factor or invented factors, such as Global Impact Factor (GIF), Universal Impact Factor (UIF), Journal Impact Factor (JIF), or Morocco-based Scientific Journal Impact Factor (SJIF). Interestingly, the entire infrastructure for 'accrediting' such journals is a business by itself; for example, a journal applying for a JIF from GISI will be charged 'a nominal fee for processing' (http://www.jifactor.com/SubmityourJournal.asp); in the past, dedicated websites displayed the fees, but now they have been removed. Furthermore, in order to look credible, such indices have values which would not draw any particular attention if they were impact factors (i.e., between 1 and 2), although they are dubiously defined. For example, the Global Impact Factor considers "factors like peer review originality, scientific quality, technical editing quality, editorial quality and regularity" (http://globalimpactfactor.com/). Similarly, the International Journal of Computers and Technology advertises in the CFP an Impact Factor of 1.532. A click on it takes the recipient to the website of the Council for Innovative Research (CIR) (http://cirworld.org/), which lists journals and their Impact Factor, 'calculated with process of IF calculation procedure of $C I R^{\prime}$, and specifies the payment methods for receiving the CIR Impact Factor. Occasionally, other indications of 'prestige' are offered; the International Journal of Engineering Science and Innovative Technology (with an address in the US - Branch: India and no name for the Chief Editor) and International Journal of Emerging Technology and Advanced Engineering include in the CFP the line "ISO 9001:2008 Certified [International] Journal".

Fake locations are not provided to the journals only, but also to those indexing their content; for example, the Sci-Afric Journal of Scientific Issues, Research and Essays provides an 'impressive' list of indexations: Advanced Science Index (Germany), Open Academic Journal Index (Russia), Researchbib (UK), Efita (USA).

In order to illustrate the 'prestige indicators', some of the elements present in the CFP received from the British Journal of Mathematics \& Computer Science are listed below:

- Fake location: the title mentions 'British', although according to their website (http://www.sciencedomains.org/contact-us.php) the Editorial Office is located in West Bengal, India and there are 'Registered Offices' in London, Delaware and Delhi. The US address is in 'One Commerce Center'

- Advanced OPEN peer review - although they state to use the system, explanations consist of a set of redirecting links, which ultimately lead to a Wikipedia description 
of 'Open Peer Review'; however, the journal does not specifically explain how the process is carried out

- Fast publication -3 weeks for a first decision, 6 for publication

- Presence in "many respected abstracting/indexing services" (CFPs received via email 2015.); the list starts with Thomson-Reuters ISI, and 'screenshots' are offered; however, the screenshots do not prove its indexation, but only citations of two papers published by the journal. The other databases are common to many other journals and do not necessarily make a quality-based selection (Polish Ministry of Science and Higher Education, Ulrich's, Google Scholar, OpenJGate, several university libraries etc.)

- Author profiles attempt to prove that the journal has been chosen by "chosen by academicians of many famous universities, institutes"

- Testimonials - although inappropriate for a journal, they are used to confirm the prestige

- 100 US dollars Article Processing Charge for submissions received during January 1 , 2015 - March 31, 2015

Across the time, several 'improvements' were made to the CFP in terms of personalization.

- Although generic invitations are most common (Eklund 2012), some journals have moved to personal approaches. When addressing the authors, some of the journals moved from impersonal formulae (Dear Researcher, Dear Professor, Dear Colleague or flattering ones, such as Dear Eminent Research Scholar) to semi-personal ones ('Dear' followed by all authors of a published paper, although the e-mail is sent to each of them separately) and even personal ones (including the name of the author). Personalized emails include ways of flattering the authors; typically, they mention another contribution and ask for republishing it (Dyrud 2014) or request a similar contribution from the author(s). For instance, a typical CFP from David Publishing (a predatory publisher pretending to be located in the US, although few clicks send the recipient to China) looks like: "Dear [Name], This is ..., a professional journal published across the United States by David Publishing Company, New York, NY, USA. We have learnt your paper "..." in ... We are very interested in your research and also would like to publish your other unpublished papers in ... If you have the idea of making our journal a vehicle for your research interests, please feel free to send electronic version of your papers or books to us through email attachment in MS word format. Currently, we are trying to invite some scholars who are willing to join our editorial board or be our reviewers. If you are interested in our journal, please send your CV to us. Hope to keep in touch by email and can publish some papers or books from you and your friends. As an American academic publishing group, we wish to become your friends if we may."

- Some other journals renew a personalized call (Journal of Environmental Analytical Chemistry), and, in this cases, even quote the previous message (BioMed Research International).

Other formulae found in the CFPs include:

- First of all we would like to congratulate you for your consistent and incessant efforts till now in the field of ... Being aware of your eminence in the related field, we cordially invite you for your valuable contribution towards our journal (Geoinformatics \& Geostatistics)

- It is truly our honor to reach you for our upcoming Special Issue on... (International Journal of Geosciences)

- You are somehow an Academics (International Research Journal of Public and Environmental Health) 
- I came across to your research paper titled ... and feel that your research is having a very good impact. With a view to begin a long-term fruitful association with you, I invite you to submit your upcoming research articles / papers for publication (Global Journal of Science Frontier Research)

- Acquiring that you have once published a paper titled ... on the theme of ... (list of the key words of the article, separated by semicolons) in ..., SciencePG believes you must have great achievements in your research field and sincerely invites you to propose a Special Issue and be its Lead Guest Editor (SciencePG).

- The time and attention you devoted for presenting a neoteric article is really palpable (SOJ Microbiology \& Infectious Diseases).

- The Journal of General Medicine - Open Access ends the CFPs by wishing recipients to "Have a Great \& Healthy day ahead!"

- Jacobs Publishers, regardless of the journal, start their CFPs with: "Hope this mail finds you in good spirit."

'Predatory conferences' use even more bombastic phrasing, when calling for speakers; an invitation to the 3rd World Congress on Cell Science \& Stem Cell Research includes the following text: "Dear Dr... Greetings. First of all, our Organization wants to honor you for your achievement and Awards. Your path and experience may guide many young researchers to be a successful scientist in the world. With your majestic presence which will take the conference to a supreme level and also will support to harness the current and future research in Cell Science \& Stem Cell Research."

Last but not least, the most recent invitations are signed by people instead of using a generic formula (Editor etc.). Four CFPs from the International Journal of Applied Science and Technology within the same day, although signed by the Chief Editor, Dr. Jorge J. Santiago-Aviles, seem to come from "Goldie Steinberg" (steinberg27.ijbss@yahoo.com), "Elena Slough" (elenaslough10@yahoo.com), “Richard Son” (sonrichard905@yahoo.com) or "Richard Harmford" (rharmford02@yahoo.co.uk). Mirroring this invitation, the CFP from the Journal of Education and Human Development is signed by the Chief Editor, Dr. Kathleen M. Everling, but sent by "john Dehner" (with ' $j$ ' instead of 'J'!) from dehner7.ijbht@yahoo.com (note the similar structure of this address with the first one, as well as the similar structure of the last three addresses from the first CFP) 'Predatory conference' invitations follow the same pattern; the invitation to the 2014 International Conference on Advanced Education Reform and Management Innovation is sent by "Prof. Wang", with a generic address (publisher15@vip.126.com), but the e-mail subject introduces a different name (bold font): "Apr.12, 2014 / 5:3" AERMI 2014: Academic Cooperation [Prof. KONG].

An interesting example is a CFP for the 2015 Global Conference on Applied Social Science (GCASS 2015) in Guangzhou, China on May 9-10, 2015; the subject is "\#Feb.1,2015 / 16:37\# DESTECH PUBLICATIONS, CFPs [Prof.TONG]". This is due to the fact that all papers (note the lack of review) will be published by DEStech Publications. The contact person is Dr. ZHENG (gcass2015@163.com); the same e-mail address is indicated for submissions, although the e-mail appears to come from "Eljournal" (scijournal02@vip.163.com). It is interesting to see that the second part of the e-mail addresses (vip.number.com) is similar in structure with the previous one. 
If all the elements mentioned earlier are found in the CFP or on the journal websites, there are several missing ones:

- Editorial structure. Most journals do not display information on the Editorial Board, owners or reviewers, or list people without having their permission (Dyrud 2014; Wehrmeijer 2014), or even when they have in vain requested to be removed (Wehrmeijer 2014).

- Originality and design. Many predatory publishers have a large fleet of journals (Crawford 2014; Schauss 2014), and use a template to quickly create each journal's homepage (Schauss 2014). The content is often pirated from other websites (Schauss 2014); for example, BRET Research Publication has created a logo which resembles Elsevier's logo (Eklund 2012). Moreover, as it has been showed previously, the names repeat partially or totally. To illustrate the statement, TimeLine Publications CFP lists a series of journals, repeating the objectives (particularized only with respect to the topic, fitting the name), or only titles and submission details.

To illustrate this, an e-mail based CFP from the International Journal of Advanced and Innovative Research (ijairmail@gmail.com), which claims to be issued by 'Company Name LLC.' Located on '29798 New Street, Anytown, USA 55555', with the contacts 'O: 555-5555555 F: 555-555-5555' introduces a series of journals from the same publisher, based in India, but with undisclosed identity (in the e-mail or on the particular websites). For each journal on a list virtually covering all subjects, the standard description is: "International Journal of ... [...] It aims to promote the research in the field of ... The focus is to publish quality papers on state-of-the-art of ...", repeating (including the title case) the words from the journal's name.

Occasionally, similarity includes logos; Figure 1 displays the logos of three publishers, Donnish Journals, Savant Journals and Swift Journals; the logos found in the CFPs do not differ in terms of design, and the ones found on their websites are very similar.

\section{watestrono \\ DonnishJournc DONNISH JOURNALS SJ SAVANTJOURNALS SAVANT JOURNALS SWIFTJOURNALS SWIFT JOURNALS}

Figure 1: Logos of Donnish Journals, Savant Journals and Swift Journals, as extracted from the CFPs and websites. The images show that the CFP logos are absolutely the same (font and color) and website logos show high similarity.

\section{Subjugation and Consumption Strategies}

Predatory journals have high, and often possibly hidden, publication charges (Truth 2012; Beall 2013; Burns 2014; Dyrud 2014; Schauss 2014), on average 900 US dollars (Wehrmeijer 2014); for example, while some of the journals show a total amount, David Publishing charges per page; despite the efforts of the authors to take a little advantage, hidden fees increase the publishing cost to approximately 1090 US dollars (Truth 2012). In many situations, the authors were not aware of the fees, but received a bill after their 
paper was published (Beall 2012b; Bohannon 2013; Butler 2013). Occasionally, the CFP suggests that authors are publishing anyway funded research, so the entire transaction is 'fair' for the authors, since they are not paying out of their own funds. Moreover, they offer 'attractive' methods of payment, such as PayPal or credit card; in reality, they are also designed to mask the true destination of funds.

Last but not least, standard advertisements - although strange to a journal - are mentioned in the CFP:

- The Open Environmental Engineering Journal offers "discounts on the Standard Open Access charges" to Members of Bentham OPEN (although this line hides the membership cost), and a fee waiver to "to authors from low-income economies" (defined by the journal)

- The Association for Development in Engineering Research (ADER) has different fees for India (2000 rupees) from all other countries (150 US dollars)

- The same journal advertises a "special discount for students and for those authors who have 2 or more paper published" - a "buy one, get one for free strategy, also used by Multidisciplinary Journal Ciência e Técnica: "authors with more than 3 published papers in the journal will be awarded to have 1 accepted paper published for free and will have free access to the journal database"

- ScienceDomain International lists on its website a series of 'facilities', including: a 100 US dollars Article Processing Charge for submissions received during January 1, 2015 March 31, 2015, which cannot be combined with any other coupon (compared with 500 US dollars regularly); discounts of $10-50 \%$ for authors from 'Low income economies', 10-40\% from 'Lower-middle-income economies', and 10-35\% from 'Upper-middleincome economies'; discounts of $30 \%$ for authors from the 'Established Author Recognition Program', and 20-50\% for 'Institutional membership'; and a 'General Discount', which can be provided considering the reasons exposed by authors in their letter. However, all these discounts apply to the 'Article Processing Charge', which is presented explicitly; the document mentions that there is another 'Publication Charge', which is hidden, and does not constitute the object of any discount. There are also 'Reprint charges', but only based on request. The apparently low (excluding the hidden Publication Charge) fee is emphasized by a long list of charges from competitors, and the comparison includes even references to the literature. In addition to discounts, the journal offers a broad selection of payment methods, including credit cards, bank transfer, money bookers, NETELLER, Liberty Reserve.

- SciencePG uses a different strategy, 'catching more fish at once'; instead of chasing for individual authors, their aim is to attract "Guest Editors", who can do the job of inviting authors; the advantages are that Guest Editors can: "publish 2 papers for free and enjoy $30 \%$ discount for your extra papers" published in their special issue, "publish 2-8 papers for free in any journal or Special Issue of SciencePG in the future according to the quantity of charged papers" in their special issues, and give invited Guest Editors and authors the right to publish papers with a $30 \%$ discount.

In addition to these strategies, more recently the predatory journals revealed their real (business) nature by borrowing a specific business advertisement terminology:

- Some journal names seem to originate from the business world: Platinum Global Journal of Social Science and Humanity;

- Typical language of advertisements announcing different discounts: "30\% waiver on the publication charges" (Journal of Architectural Engineering Technology), "lower than average paper fees" (Scholars World - International Refereed Multidisciplinary Journal of Contemporary Research), "1st Paper 50\% off, 2nd Paper for Free", "up to 80\% off 
Paper Publication" and "the 50th Book Published for Free" (Open Science), "Special Offers for Paper Publication" or "2 papers for free and 30\% discount for the rest" (SciencePG), "Free Publication" (CIBTech Scientific Journals), "join AASCIT Membership to Publish Papers for Free" or "all valid members of AASCIT can publish papers in the specified 17 journals for free from July 1, 2015 to August 31, 2015. Except for the afore mentioned 17 journals, the members can also publish papers with a 50 percent discount in the rest journals" - please note also the English level, contrasting with a claimed 'American' Association (American Association for Science and Technology), "last chance to register with discount price" (Journal of Functional Foods in Health and Disease), "membership program" (Journal of Biodiversity Management \& Forestry)

- The CFP from Science and Education Publishing is actually a list of titles and prices (which are actually the same), without any mention of the particularities of any journal; similarly, the CFP from the International Research Journal of Engineering and Technology mentions (among advantages!) that "authors can pay online 24/7 using Credit card, Debit Card, Net Banking, Cash Card, Paypal etc." Obviously, in all these cases the focus is on fees, not journals.

- In addition to the terminology, even the graphic language used in the CFPs is borrowing from the business world. Figure 2 shows images included in the CFPs received from SciencePG; the images are typical to a product advertisement focused on price instead of quality. Occasionally, even the subject of CFPs uses a similar pricing or servicesfocused language (in bold): "Special Offers for Paper Publication" (SciencePG), "Dear [...], Publish Your Paper for Free as an AASCIT Member" (American Association for Science and Technology), "Call for paper - 2015 / Affordable Publishing price \& Rapid Peer review" (Herbert Publications), "Invites you to submit research paper for publishing Low cost" (Global Journal of Advanced Research).

\section{Special Offer for Paper Publication}
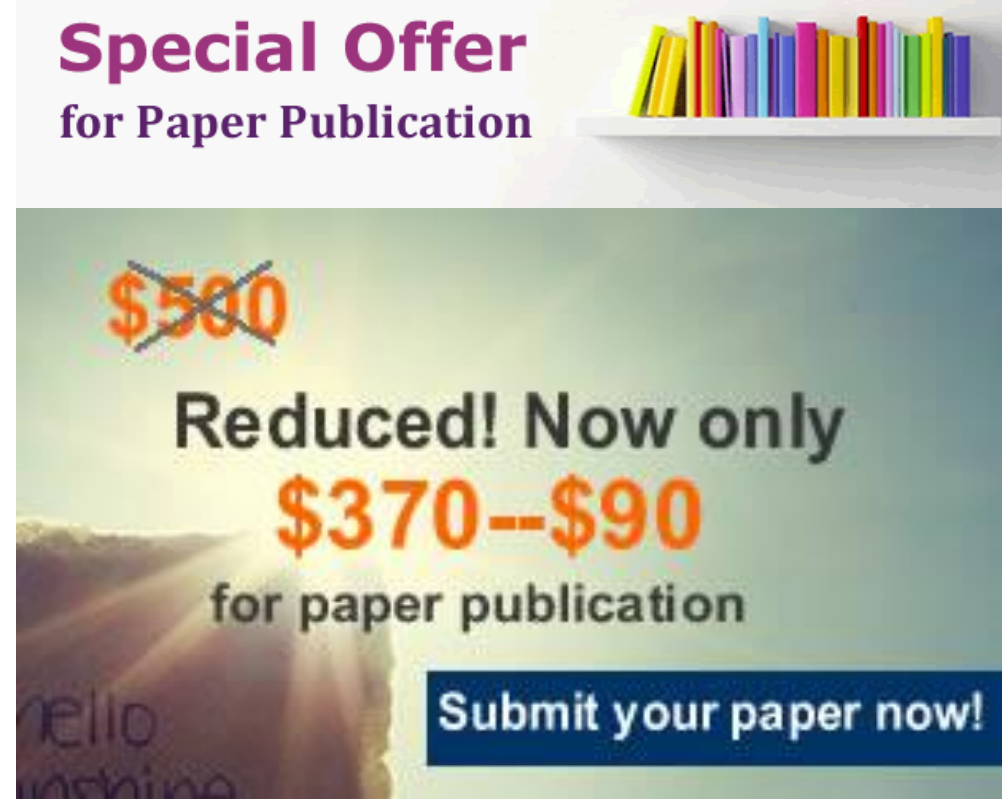

Figure 2: Advertisements included in the CFPs from SciencePG. The content is typical to a product advertisement and focused on price instead of quality 


\section{General Strategies}

Predatory journals seem to attract the less privileged scientists (Truth 2012). Several of the underlying reasons for accepting such invitations, even when they know or suspect the fraud, include:

- Language. The poor language of the CFP and published papers (Eklund 2012; Truth 2012; Bohannon 2013; Crawford 2014) gives hope to authors for whom English is not the native language that their article can be published. The alternative offered by nonpredatory journals, which charge for their language services, can be equally expensive. Examples of the language level can be perfectly illustrated by few samples from the CFP sent by the Integrated Journal of Engineering Research and Technology: "Its our pleasure to inform you that Integrated Journal of Engineering Research and Technology Successfully Launched Nov-Dec, 2014, Issue-6. We are thankful to All Author/Researcher, Editor and Advisory Board member and all team members of Society of Scientific Research (SSR) to make it successful. We Promise our Worldwide Researcher to provide High Security to Article and quality to their Research Article. If you wish to publish your Valuable Research/Review Article/ Case Study in Volume 2, 2015, Issue 1, Jan-Feb, Submit it for Publication in Integrated Journal on editorijertco@gmail.com. Integrated Journal indexed various reputed indexing agencies like International Impact Factor Services, SOCOLAR China, Research Bible Fuchu Tokyo JAPAN, Indian Science Publication, Scientific Indexing Services, Directory of Research Journal Indexing, Cite factor, Research Gate, Google Scholar etc.", or Global Journal of Advanced Research: "We are send the procedure for Submit Paper or Article and publishing this. All information given below. [...] If you want submit the Article without registration using this link Click... [...] After submit paper using following procedure by us: [...] Third Stage Editor board gives this conformation to author by mail. If paper is accepted then editor will also give account detail for Copyright form. [...] Fourth Stage -Author will be submit scan copy of copyright form which is download form."

- Publication pressure. The 'publish or perish' principle comes into place when predatory journals propose authors to become a vehicle for disseminating their results (Truth 2012).

- Openness. Metrics-dominated procedures for advancement in research or teaching have led to a rush for citations (Lawrence 2007). By providing open access and cutting off the reading costs, predatory journals give authors a hope for more citations (Truth 2012). In fact, most CFPs mention openness as a "paramount request" (International Research Journal of Public and Environmental Health) or "key request" (Merit Research Journals) of worldwide researchers. Similarly, the Pacesetter Journal of Agricultural Science Research states that: "One key request of researchers across the world is unrestricted access to research publications. Open access gives a worldwide audience larger than that of any subscription-based journal and thus increases the visibility and impact of published works. It also enhances indexing, retrieval power and eliminates the need for permissions to reproduce and distribute content".

- Acceptance rate. Predatory journals have showed consistently high acceptance rates; papers were accepted with little or no peer review (Bohannon 2013; Bartholomew 2014; Dyrud 2014; Wehrmeijer 2014), and often the copy-editing process was bypassed (Wehrmeijer 2014). This situation was revealed by Bohannon's 'sting operation', where "acceptance was the norm, not the exception" (Bohannon 2013). For instance, the International Journal of Emerging Technology and Advanced Engineering (with an Editorial Board including "200t" members) advertises in its CFP an acceptance rate of $10: 1.5$ ! However, the real criteria of peer review are not always obvious. They are often masked by expressions like "robust and neutral" (Journal of Global Economics, Management and Business Research), "rigid" (International Journal of Advanced 
Computer Technology), "transparent and high standard [...] respected and toughest Advanced OPEN peer-review system" (British Journal of Applied Science \& Technology), based on the "prevalent criteria of significance, relevance and scientific excellence" (Journal of Biodiversity Management \& Forestry) or "general criteria of significance, relevance and scientific excellence" (Sky Journal of Agricultural Research). In other situations, journals describe an iterative process, focused on a step-by-step assisted improvement of paper (Sky Journals of Biochemistry Research), focus on "improving papers instead of only publishing them" (WatchPlus) or encourage "post-publication peer review" (British Journal of Applied Science \& Technology). Very few journals disclose the criteria; the CFP from Pak Publishing Group starts with a strong statement: "The bogus peer review is becoming a real concern among academics with numerous journals accepting papers without adequate levels of peer review, only for financial motives. You understandably want to be assured that your paper is published by a reputable and ethical journal, with high-quality peer review", but later the nature of their peer-review is explained: "We don't reject articles purely on the grounds of supposed importance." On a similar note, "submissions are evaluated for methodological soundness and scientific relevance, rather than perceived level of future importance" by the Asian Journal of Economics and Empirical Research, and "according to the content and methods employed" by the Elective Medicine Journal.

- Multiple publication. Often the same author can publish more papers, even in the same issue (Crawford, 2014), and is actually encouraged to do it through the discounts. This statement has already been supported by some of the examples presented before.

- Publication of other items than articles, including audio and video versions of articles (Enliven: Bio Analytical Techniques), or "research images, video articles" (Journal of Astrobiology \& Outreach)

- Publicity for published articles. Herbert Publications advertise the following: "Article-Level Metrics (ALM), DOI-Cross ref, CrossCheck, Cross Mark Policy, MathJax, Epub, News Letters, Cited-by Linking, Reprints, Article Metrics (provide clear insights about Article views, PDF downloads, citation of articles (Crossref Citation Tool)), Social promotions (Facebook, Googlet, Twitter), Comments on article, related articles in Google Scholor, Indexed sources like PubMed, Europe PubMed". Similarly, the Journal of Biosensors \& Bioelectronics promises to share published articles "in social networking like Facebook, twitter, LinkedIn, RSS feeds, etc."

- Certificates. For example, the Association for Development in Engineering Research (ADER) provides an "individual eCertificate to each author"

- Services. In fact, the service offer is a clear indication that predatory publishers regard themselves as (publication) services providers rather than quality content deliverers. The following examples sustain this claim: "friendly responsive staff" (Merit Research Journal of Education and Review), "24/7 E-mail support / Immediate Response" (Research Journal of Engineering and Technology)

- Other advantages include: free English language assistance and a simple and standard paper template (!) - International Journal of Advanced Research in Chemical Science, "Zero Waiting Time" for the publication of accepted manuscripts (Journal of Emerging Trends in Computing and Information Sciences), no length constraints for submissions (Biochemistry \& Molecular Biology Letters), or publication of manuscripts in a "secured format" (Journal of Current Computer Science and Technology)

Most of these strategies are illustrated by a CFP from 'The Open Environmental Engineering Journal' mentioning the following advantages of authors "compared to a traditional subscription journal":

- "Articles can be read by a potentially much larger audience; 
- Published articles are FREE to view, download and to print;

- Articles have the potential to obtain greater citations;

- Authors own the copyright to their published articles under a non-commercial license;

- Articles are peer-reviewed and published rapidly."

However, advantages are not always mentioned or realistic. The CFP from the Journal of Global Resources mentions only its 'international' status and the fact that it will be published "thrice a year", but also the fact that the publication has only applied for an ISSN, a key condition for any serial. Similarly, SciencePG mentions as a possible advantage of a Guest Editor building their own editorial team and exchanging ideas with them. Also, the International Journal of Advanced Computer Technology is edited online and its content can be accessed freely, but the corresponding author receives a... "soft copy of the journal"!

One final strategy seems to read 'behind the lines' and can only be presumed; the article discussed in detail several examples and pointed out very many common elements, such as the structure of calls or e-mail addresses, similar wording, websites, strategies, and even mistakes. The similarity can be attributed to replicating the model, but there is a possibility that some of these businesses are coordinated together and they do not compete against each other, as it would seem at a first glance, even when the journals or publishers are located in different countries. For example, when looking at two calls, one from the American International Journal of Social Science edited by the Center for Promoting Ideas, and the Journal of Geography and Earth Sciences, edited by the American Research Institute for Policy Development, with both publishers claimed to be located in the United States, both calls contain in the e-mail address the initials of the last publisher: the first call comes from Aaidyn Braedon (aaidyn.aripd19@yahoo.com), and the second is sent to aripd.jges@gmail.com.

\section{CONCLUSION}

In ecology, the system predator-prey has evolved continuously; evolutionary ecology offers countless examples of how the predators developed new strategies for capturing their prey, and how predated species developed their own strategies to evade from the attack. The same is true for predatory journals; the academic community reacted; and in addition to the numerous papers published in journals from all fields, websites were created. The social media - including social academic media - plays an important role. Nevertheless, predatory publishers and journals have responded with new strategies; to name one of them, hijacking seemed to have deceived authors who were already immune to calls from the 'Global Journal of...'. Unfortunately, the pressure to publish and get cited creates a competitive advantage, especially when researchers do not pay out of their own funds.

Perhaps the new way of making science, turning it into a business, is one of the causes that gave birth to predatory journals. Another cause might be a re-interpretation of the classical 'publish or perish' distorted by science metrics; several consequences are the need to publish abroad and, if possible, in a country with higher-rated journals, the need to be visible in order to be cited (in the context of an evolving electronic 'publishing ecosystem'), and the need to publish fast. If this is the case, a return to the science for the sake of science or the benefit of society is a possible solution. 


\section{ACKNOWLEDGEMENT}

This research received no specific grant from any funding agency in the public, commercial, or not-for-profit sectors. The author would like to thank the anonymous reviewers for the time taken during the review process and for their constructive criticisms, which resulted into a substantial improvement of the quality of the manuscript. Special thanks are due to all predatory journals, conferences and publishers who had sent CFPs during the last years, providing - free of any charge - sufficient evidence for illustrating the points presented in this article.

\section{REFERENCES}

Anderson, R. 2014. Housecleaning at the Directory of Open Access Journals. Available at: http://scholarlykitchen.sspnet.org/2014/08/14/housecleaning-at-the-directory-of open-access-journals/.

Bartholomew, E. R. 2014. Science for sale: The rise of predatory journals. Journal of the Royal Society of Medicine, Vol.107, no.10: 384-385.

Beall, J. 2010a. "Predatory" open-access scholarly publishers. The Charleston Advisor, Vol.11, no.4: 10-17.

Beall, J. 2010b. Update: Predatory open-access scholarly publishers. The Charleston Advisor, Vol.12, no.1: 50.

Beall, J. 2012a. International prank involving predatory publishers makes headlines in Indonesia. Available at: http://scholarlyoa.com/2012/08/31/international-prankinvolving-predatory-publishers-makes-headlines-in-indonesia/.

Beall, J. 2012b. Predatory publishers are corrupting open access. Nature, Vol.449, no.7415: 789.

Beall, J. 2013. Predatory publishing is just one of the consequences of Gold Open Access. Learned Publishing, Vol.26, no.2: 79-84.

Beall, J. 2015. Scholarly Open Access. Critical analysis of scholarly open-access publishing. Available at: http://scholarlyoa.com/

Bohannon, J. 2013. Who's afraid of peer review? Science, Vol.342, no.6154: 60-65.

Burns, P. 2014. Adventures with predatory publishing: A tale of two Journals. FrontMatter, Vol.29: 2-8.

Butler, D. 2013. The dark side of publishing. Nature, Vol.495, no.7442: 433-435.

Butler-Adam, J. 2014. Dealing with 'open access' demons. South African Journal of Science, Vol.110, no.5/6:\#a0070.

Crawford, W. 2014. Journals, "Journals" and wannabes: Investigating the list. Cites \& Insights, Vol.14, no.7: 1-45.

Dyrud, A. M. 2014. Predatory online technical journals: A question of ethics. Paper presented at the 121st ASEE Annual Conference \& Exposition, June 1914, Indianapolis, IN, USA (No. 8413).

Easterbrook, H. F. 1981. Predatory strategies and counterstrategies, 48 University of Chicago Law Review, Vol.263, no.2: 263-337.

Eklund, P. 2012. Open Access and predatory publishers. A guide to reviewing open access journals. Borås, Sweden: University of Borås. Available at: http://hdl.handle.net/2320/11421.

Eldredge, N. 2012. Mathgen paper accepted! Available at: http://thatsmathematics.com/ blog/archives/102. 
Endler, A. J. 1986. Defense against predators, In: M. E. Feder, G. V. Lauder, eds. Predatorprey relationships. Perspectives and approaches from the study of lower vertebrates. Chicago, IL, USA: University of Chicago Press: 109-134.

Fiebert, S. M. 2014. A look at Open Access publication and Beall's List of "Predatory" journals. Global Journal of Interdisciplinary Social Sciences, Vol.3, no.4: 5-6.

Haug, C. 2013. The downside of open-access publishing. New England Journal of Medicine, Vol.368, no.9: 791-793.

Jalalian, M. and Mahboobi, H. 2013. New corruption detected: Bogus Impact Factors compiled by fake organizations. Electronic Physician, Vol.5, no.3: 685-686.

Lawrence, A. P. 2007. The mismeasurement of science. Current Biology, Vol.17, no.15: R583-R585.

Lukić, T.; Blešić, I.; Basarin, B.; Ivanović B.L.; Milošević, D. and Sakulski, D. 2014. Predatory and fake scientific journals/publishers - A global outbreak with rising trend: A review. Geographica Pannonica, Vol.18, no.3: 69-81.

Schauss, G. A. 2014. Beware of predators. Nutritional Outlook, Vol.17, no.7: 22-27.

Truth, F. 2012. Pay big to publish fast: Academic journal rackets. Journal for Critical Education Policy Studies, Vol.10, no.2: 55-105.

Wehrmeijer, M. 2014. Exposing the predators. Methods to stop predatory journals. Master Thesis. Leiden, The Netherlands: Leiden University. Available at: https://openaccess.leidenuniv.nl/handle/1887/28943. 